\title{
Antibacterial Activities of Ankaferd Hemostat (ABS) on Shiga Toxin-Producing Escherichia coli and Other Pathogens Significant in Foodborne Diseases
}

\author{
Ankaferd Hemostat'ın (ABS) Shiga Toksijenik Escherichia coli ve Diğer Gıda Patojenleri \\ Üzerine Antibakteriyel Etkisi
}

\author{
Ahmet Koluman¹, Nejat Akar², ibrahim C. Haznedaroğlu³ \\ ${ }^{1}$ Republic of Turkey Ministry of Food, National Food Reference Laboratory, Department of Mineral Analyses, Agriculture, and Livestock, Ankara, \\ Turkey \\ 2TOBB-ETU Hospital, Clinic of Pediatric Hematology, Ankara, Turkey \\ ${ }^{3}$ Hacettepe University Faculty of Medicine, Department of Adult Hematology, Ankara, Turkey
}

\section{Abstract}

Objective: Ankaferd hemostat (Ankaferd Blood Stopper ${ }^{\circledR}$, ABS)induced pharmacological modulation of essential erythroid proteins can cause vital erythroid aggregation via acting on fibrinogen gamma. Topical endoscopic ABS application is effective in the controlling of gastrointestinal (GI) system hemorrhages and/or infected GI wounds. Escherichia coli 0157:H7, the predominant serotype of enterohemorrhagic $E$. coli, is a cause of both outbreaks and sporadic cases of hemorrhagic colitis. The aim of this study is to examine the effects of ABS on 6 different Shiga toxigenic E. coli serotypes including 026, 0103, 0104, 0111, 0145, and 0157 and on other pathogens significant in foodborne diseases, such as Salmonella Typhimurium, Campylobacter jejuni, and Listeria monocytogenes, were also assessed.

Materials and Methods: All strains were applied with different amounts of $A B S$ and antimicrobial effect was screened. S. Typhimurium groups were screened for survival using the fluorescence in situ hybridization technique.

Results: The relative efficacy of ABS solutions to achieve significant logarithmic reduction in foodborne pathogens E. coli 0157:H7 and non-0157 serogroups and other emerging foodborne pathogens is demonstrated in this study. ABS has antibacterial effects.

Conclusion: Our present study indicated for the first time that ABS may act against E. coli 0157:H7, which is a cause of thrombotic thrombocytopenic purpura, hemolytic-uremic syndrome, and hemorrhagic colitis. The interrelationships between colitis, infection, and hemostasis within the context of ABS application should be further investigated in future studies.

Keywords: Ankaferd Blood Stopper, Shiga-toxigenic Escherichia coli, Salmonella, Campylobacter, Listeria monocytogenes
Öz

Amaç: Ankaferd hemostat (Ankaferd Blood Stopper $\left.{ }^{\circledR}, A B S\right)$ gamma fibrinojene etki ederek eritroid agregasyonuna neden olan farmakolojik modülasyondur. Topikal endoskopik ABS uygulaması gastrointestinal (Gi) kanamalarda ve enfekte Gi yaralarında etkili olmaktadır. Escherichia coli 0157:H7, en sık karşılaşılan enterohemorajik Escherichia coli tipi olup sporadik veya salgınlar şeklinde hemorajik kolitin önemli bir etkenidir. Bu çalışmanın amacı ABS ile 6 farklı Shiga Toksijenik Escherichia coli serotipi (026, 0103, 0104, 0111, 0145 ve 0157) ve diğer önemli gıda kaynaklı patojenlerden Salmonella, Campylobacter ve Listeria monocytogenes üzerine etkisi değerlendirilmiştir.

Gereç ve Yöntemler: Tüm patojenler hazırlanarak ABS'nin farklı miktarları uygulanmış ve antimikrobiyel etki izlenmiştir. Salmonella canlıığı floresan in situ hibridizasyon tekniği ile izlenmiştir.

Bulgular: ABS uygulamalarının sadece Escherichia coli 0157 ve non0157'ler üzerine değil aynı zamanda diğer patojenlerde de logaritmik azalma tetiklediği izlenmiştir. Bu çalışmada ABS ile farklı patojenler üzerine antibakteriyel etki gözlemlenmiştir.

Sonuç: $\mathrm{Bu}$ çalışma özellikle trombositopenik purpura, hemolitik üremik sendrom ve hemorajik kolit yönünden önemli Escherichia coli 0157:H7'nin üzerine ABS'nin antimikrobiyel etkisi olduğunu belirleyen ilk çalışmadır. ABS uygulamalarının kolitis, enfeksiyon ve hemostaz ilişkisi daha ileri seviyede araştırılmalıdır.

Anahtar Sözcükler: Ankaferd Blood Stopper, Shigatoksijenik Escherichia coli, Salmonella, Campylobacter, Listeria monocytogenes 


\section{Introduction}

Ankaferd hemostat [Ankaferd Blood Stopper $\left.{ }^{\oplus},(A B S)\right]$; http:// www.ncbi.nlm.nih.gov/pubmed/?term=ankaferd) is the first topical hemostatic agent regarding red blood cell (RBC)fibrinogen interactions tested in clinical trials [1]. ABS is composed of standardized plant extracts including Alpinia officinarum, Glycyrrhiza glabra, Thymus vulgaris, Urtica dioica, and Vitis vinifera [2]. ABS-induced pharmacological modulation of essential erythroid proteins (ankyrin, spectrin, actin) can cause vital erythroid aggregation by acting on fibrinogen gamma [3]. ABS also has pleiotropic effects, particularly in tissue healing, and has significant antiinfective properties $[4,5,6,7,8]$. The use of $A B S$ in gastrointestinal (GI) system hemorrhages to control bleeding and/or infected GI wounds is also evident [9].

Escherichia coli 0157:H7, the predominant serotype of enterohemorrhagic E. coli (EHEC), is a cause of both outbreaks and sporadic cases of hemorrhagic colitis [10]. Infection with E. coli 0157:H7 presents with many complicated clinically abnormal hemostatic manifestations such as bloody diarrhea, hemolytic-uremic syndrome, or thrombotic thrombocytopenic purpura [11].

The aim of this study is to determine the effects of ABS on 6 different Shiga toxigenic E. coli (STEC) serotypes including 026, 0103, 0104, 0111, 0145, and 0157. Moreover, the effects of ABS on other pathogens significant in foodborne diseases, such as Salmonella Typhimurium, Campylobacter jejuni, and Listeria monocytogenes, were also assessed. Elucidation of the effects of $A B S$ on enterohemorrhagic bacteria is clinically important since there is a close pathobiological interrelationship between hemorrhages and hemostasis in terms of both diagnosis and management.

\section{Materials and Methods}

Thirty milliliters of ABS (Immune Drug Company, i̇stanbul, Turkey) was transferred to the laboratory under cold chain in a residue-free sterile tube. The sample was used for analyses within 30 min of arrival. Six different STEC serotypes, including 026, 0103, 0104, 0111, 0145, and 0157 ATCC 43895 (obtained from Istituto Superiore di Sanita, Rome, and the Public Health Institution of Turkey), and Salmonella typhimurium ATCC 14028 (Microbiologics, UK), Campylobacter jejuni ATCC 33560 (Microbiologics, UK), and Listeria monocytogenes ATCC 19115 (Microbiologics, UK) were used in this study in order to assess the effects of $A B S$.

The cultures were stored at $-80{ }^{\circ} \mathrm{C}$. After thawing on ice, each strain (excluding Campylobacter jejuni) was incubated separately in $5 \times 10 \mathrm{~mL}$ of brain-heart infusion (BHI) broth (Oxoid, UK) at $37{ }^{\circ} \mathrm{C}$ overnight. The cultures were passaged in BHI 3 times. The final cultures $(5 \times 10 \mathrm{~mL})$ were centrifuged
(Eppendorf) at $4200 \mathrm{rpm}$ and $4{ }^{\circ} \mathrm{C}$ for $5 \mathrm{~min}$. The supernatants were discarded, and pellets were resuspended and washed with $10 \mathrm{~mL}$ of sterile $0.9 \% \mathrm{NaCl}$. After washing, all suspensions were recentrifuged to remove organic residues. The resulting pellets were resuspended using sterile normal saline, and all strains were collected separately in a single tube. This stock culture was further diluted with $50 \mathrm{~mL}$ of sterile BHI broth to achieve a target level of $10^{7}$ to $10^{8} \mathrm{cfu} / \mathrm{mL}$, which is accepted as sufficient for decontamination studies.

Campylobacter jejuni was streaked on 10 plates with charcoal cefoperazone deoxycholate modified agar (Oxoid, UK) with a sterile swab and incubated under microaerophilic conditions (Campygen, Oxoid, UK) at $42^{\circ} \mathrm{C}$ for $48 \mathrm{~h}$. The grayish colonies were collected into a centrifuge tube with a swab and the mixtures were centrifuged (Eppendorf) at $4200 \mathrm{rpm}$ and $4{ }^{\circ} \mathrm{C}$ for $5 \mathrm{~min}$. The supernatants were discarded, and pellets were resuspended and washed with $10 \mathrm{~mL}$ of sterile $0.9 \% \mathrm{NaCl}$. After washing, all pellets were recentrifuged to remove organic residues. The resulting pellets were resuspended using sterile normal saline, and all strains were collected separately in a single tube. This stock culture was further diluted with $50 \mathrm{~mL}$ of sterile Bolton broth (Oxoid, UK) to achieve a target level of $10^{7}$ to $10^{8} \mathrm{cfu} / \mathrm{mL}$, which is accepted as sufficient for decontamination studies. All tubes were labeled and grouped into 2 separate groups. Tubes in group 1 were inoculated with $500 \mu \mathrm{L}$ of ABS (per $50 \mathrm{~mL}$, $1 \% \mathrm{v} / \mathrm{v}$ ), and tubes in group 2 were inoculated with $1000 \mu \mathrm{L}$ of $A B S$ (per $50 \mathrm{~mL}, 2 \% \mathrm{v} / \mathrm{v}$ ). All tubes were incubated at 37 ${ }^{\circ} \mathrm{C}$ under microaerophilic conditions to demonstrate the gut conditions, and samplings from these tubes were made at 5,15 , 30 , and 60 min after inoculation. Next, $100 \mu \mathrm{L}$ of these mixtures were spread-plated using a Spiral Plater (IUL, UK) on duplicate petri dishes of xylose lysine deoxycholate agar (Oxoid, UK) for Salmonella; MacConkey agar with sorbitol, cefixime, and tellurite agar (Oxoid, UK) for STEC; and chromogenic Listeria agar (Oxoid, UK) for L. monocytogenes and incubated at 37 ${ }^{\circ} \mathrm{C}$ aerobically for $24 \mathrm{~h}$ for all strains except Campylobacter jejuni, which was incubated under microaerophilic conditions (Campygen, Oxoid, UK) at $42^{\circ} \mathrm{C}$ for $48 \mathrm{~h}$. At the end of incubation period all typical colonies were counted and recorded.

S. Typhimurium groups were screened for survival using the fluorescence in situ hybridization (FISH) technique. Vermicon kits were used for this step. The study was composed of 3 independent trials and 9 tubes were analyzed at each step. The numbers of pathogens were converted to $\log _{10} \mathrm{cfu} / \mathrm{g}$. The data were subjected to one-way analysis of variance (ANOVA) according to a (pathogen $x$ treatment) 9x2 factorial design. The means were separated using Fisher's least square differences method according to general linear models. Statistical significance level was accepted as 0.05 . Statistical analyses were performed using Statistical Analysis System Software version 8 (SAS Inc., USA). 


\section{Results}

The results indicating the effects of $A B S$ on the studied bacteria are depicted in Tables 1 and 2. The relative efficacy of ABS solutions to achieve significant logarithmic reduction in foodborne pathogens E. coli 0157:H7 and non-0157 serogroups and other emerging foodborne pathogens is also presented in Tables 1 and 2. According to the tables, 1\% (v/v) application of $A B S$ is not sufficient to obtain a significant decrease in the numbers of pathogens. On the contrary, 2\% (v/v) application causes a dramatic decrease of the pathogens of concern. It was shown that by the end of the $60^{\text {th }}$ minute of application $2 \%$ (v/v) ABS causes a $4 \log _{10}$ cfu/mL decrease, which was significant for all pathogens. The most significant decrease was recorded in Campylobacter jejuni, which is known for higher susceptibility to environmental and chemical changes.

In Figure 1, photographs of two different applications on $S$. Typhimurium are provided. In the first group it can be clearly seen that sterile distilled water application had no effect on the survival of the pathogen. On the contrary, the second group of images clearly indicates the death of the pathogens with $2 \mathrm{~mL}$ of $A B S$.

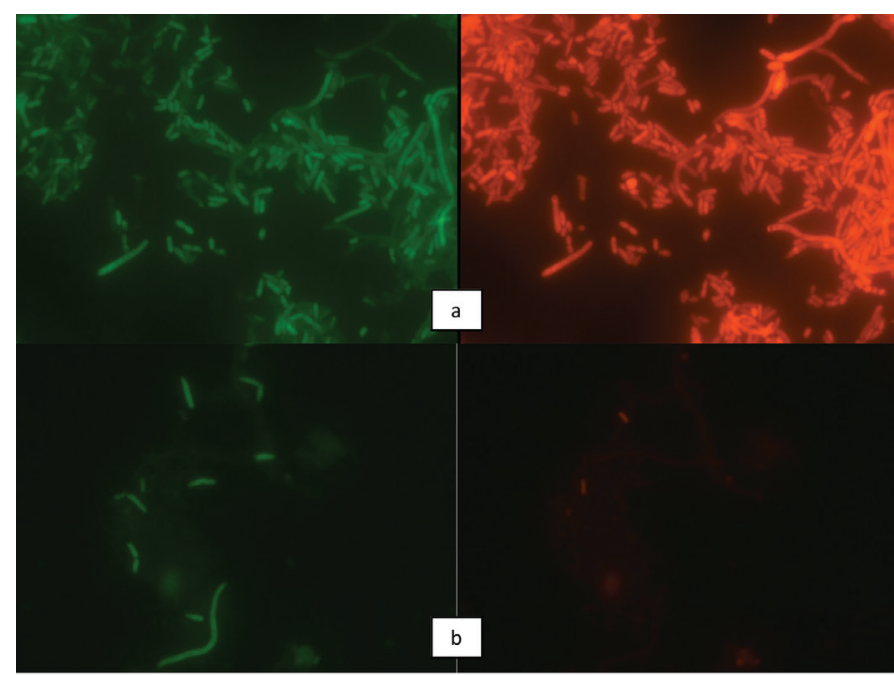

Figure 1. Effect of Ankaferd Blood Stopper, (ABS) on survival of $S$. Typhimurium (fluorescence in situ hybridization technique using Vermicon kit): a) Survival of S. Typhimurium with $2 \mathrm{~mL}$ of sterile distilled water at $37^{\circ} \mathrm{C}$. There is no visible change. Plating of the homogenate indicates the stability in the viable counts. b) Survival of S. Typhimurium with $2 \mathrm{~mL}$ of ABS at $37^{\circ} \mathrm{C}$. There is 3 $\log _{10} \mathrm{cfu} / \mathrm{mL}$ decrease, which indicates a statistical significance.

\section{Table 1. The Shiga toxigenic Escherichia coli results of the study in group 1 (sterile distilled water application) and group 2 [Ankaferd hemostat (ABS) application].}

\section{Group 1}

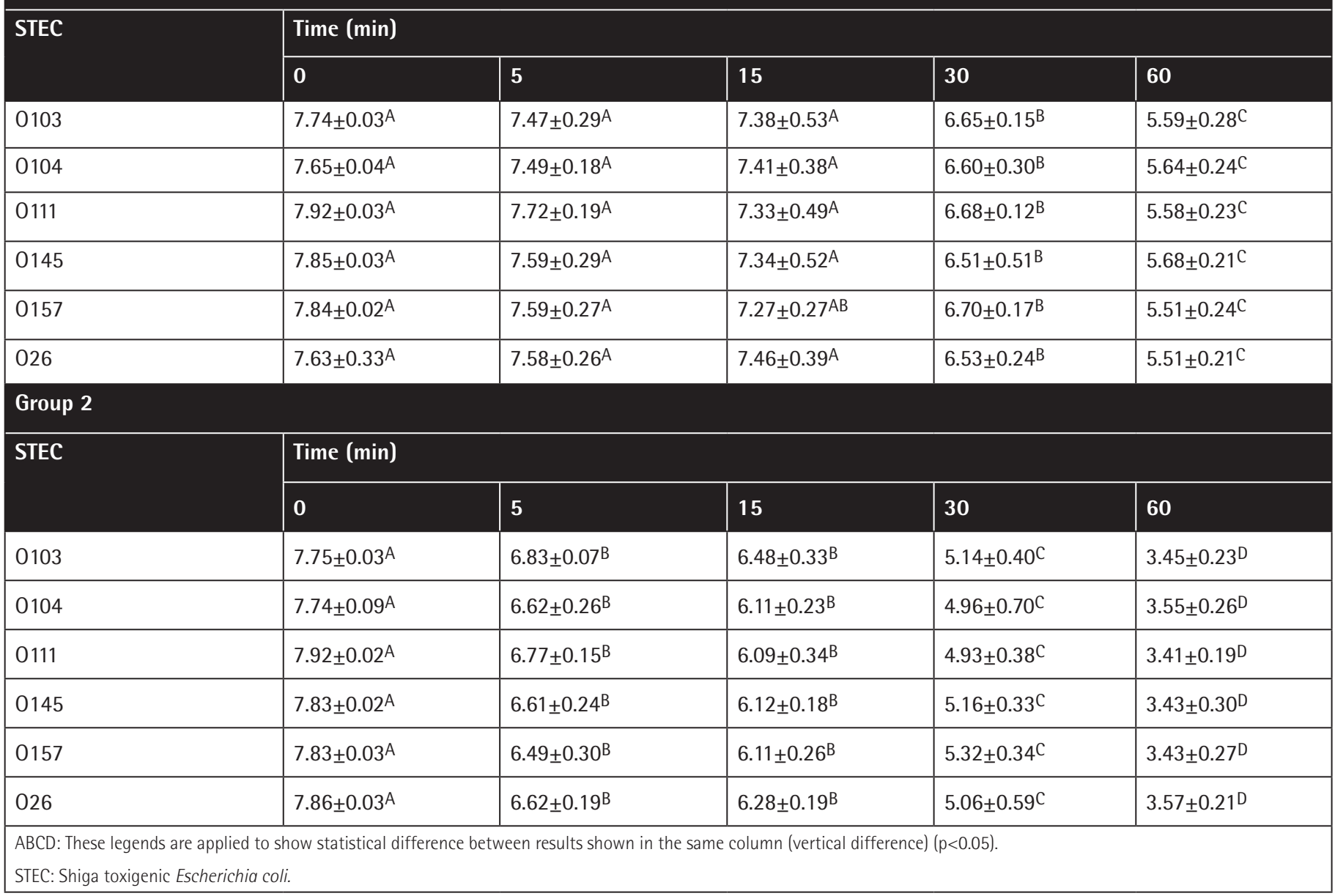




\begin{tabular}{|c|c|c|c|c|c|}
\hline \multicolumn{6}{|l|}{ S. Typhimurium } \\
\hline \multirow{2}{*}{ Volume of ABS Applied } & \multicolumn{5}{|l|}{ Time (min) } \\
\hline & $\mathbf{0}$ & 5 & 15 & 30 & 60 \\
\hline Group 2 & $7.82 \pm 0.09^{\mathrm{AX}}$ & $6.62 \pm 0.24^{\mathrm{BY}}$ & $5.94 \pm 0.34^{\mathrm{CY}}$ & $5.08 \pm 0.46^{\mathrm{DY}}$ & $3.33 \pm 0.43^{\mathrm{EY}}$ \\
\hline \multicolumn{6}{|l|}{ Listeria monocytogenes } \\
\hline \multirow[t]{2}{*}{ Volume of ABS Applied } & \multicolumn{5}{|l|}{ Time (min) } \\
\hline & $\mathbf{0}$ & 5 & 15 & 30 & 60 \\
\hline \multicolumn{6}{|l|}{ Campylobacter jejuni } \\
\hline \multirow{2}{*}{ Volume of ABS Applied } & \multicolumn{5}{|l|}{ Time (min) } \\
\hline & $\mathbf{0}$ & 5 & 15 & 30 & 60 \\
\hline Group 1 & $7.23 \pm 0.02^{\mathrm{AX}}$ & $6.93 \pm 0.10^{A X}$ & $6.65 \pm 0.34^{\mathrm{ABX}}$ & $6.04 \pm 0.21^{\mathrm{BX}}$ & $5.48 \pm 0.30^{\mathrm{BX}}$ \\
\hline Group 2 & $7.25 \pm 0.03^{A X}$ & $6.55 \pm 0.29^{\mathrm{BX}}$ & $5.59 \pm 0.38^{\mathrm{CY}}$ & $4.51 \pm 0.76^{\mathrm{DY}}$ & $2.56 \pm 0.35^{\mathrm{EY}}$ \\
\hline
\end{tabular}

\section{Discussion}

In this study, $A B S$ was found to be effective against 6 different STEC serotypes, including 026, 0103, 0104, 0111, 0145, and 0157, and Salmonella typhimurium and Listeria monocytogenes. Previous studies indicated that ABS might be used as a supportive agent together with antituberculous drugs during debridement of osteomyelitis and lymphadenitis lesions caused by multidrug-resistant Mycobacterium tuberculosis [4]. Oral/endoscopic ABS administration has already been performed in GI hemorrhages $[9,12,13,14,15,16,17,18,19,20,21,22$, 23]. Moreover, $A B S$ is active against multiresistant bacteria, such as methicillin-resistant Staphylococcus aureus, Enterococcus spp., generic E. coli, Klebsiella spp., Acinetobacter spp., and Pseudomonas spp., as well as fungi such as Aspergillus spp., Mucor spp., and Candida albicans $[4,5,6,7,8]$. Our findings in this study further support previous research findings that $A B S$ has antibacterial effects.

EHEC 0157:H7 is associated with hemorrhagic colitis, thrombotic thrombocytopenic purpura, and hemolytic-uremic syndrome in humans [24]. EHEC 0157:H7 infection can masquerade as GI bleeding of noninfectious cause, and the antecedent diarrhea may be resolved and forgotten by the time the hemolytic uremic syndrome or thrombotic thrombocytopenic purpura is diagnosed [25]. On the other hand, ABS represents an effective alternative treatment modality for GI bleeding, either as a primary or an adjuvant agent to conventional antihemorrhagic methods. The
ABS GI data from published reports with encouraging results proved the safety and efficiency of ABS as a hemostatic agent for distinct states of GI bleeding. ABS is clinically effective in bleeding individuals with normal hemostatic parameters and in patients with deficient primary hemostasis and/or secondary hemostasis $[9,12,13,14,15,16,17,18,19,20,21,23,26,27,28,29,30$, $31,32,33,34,35,36]$. ABS may act as a topical biological response modifier as well as having antihemorrhagic actions. Our present study indicates for the first time that ABS may act against E. coli 0157:H7, which is a cause of hemorrhagic colitis [10]. Difficult cases of infected bleeding radiation colitis have already been managed with ABS $[9,19,36,37,38]$. The interrelationships between colitis, infection, and hemostasis within the context of ABS application remain to be elucidated.

Infection, hemostasis, and wound healing are closely related pathobiological events to each other [39]. Next-generation RBC-related hemostatics, such as ABS nanohemostat, have been designated in the essential treatment of life-threatening bleedings by restoring physiological hemostasis via acting on RBCs [40]. Prohemostatic and antithrombin activities of $A B S$ are linked to fibrinogen gamma chain and prothrombin by functional proteomic analyses. Those unique hemostatic properties of ABS provide a balanced hemostasis, representing a basis for physiological wound healing [3]. The proteomics of the structural and functional properties of the proteins related to the wound healing should also be matched with the already established proteomics of ABS [41]. Experimental trials indicated 
that $A B S$ is effective in wound healing $[39,42,43,44,45,46,47]$. The results of our present study disclosed that $A B S$ has antimicrobial effects against bacteria that are active in wound and burn complications.

The use of plant extracts and phytochemicals with established antimicrobial properties could be of great significance in preventive and/or therapeutic approaches. The increasing prevalence of multidrug-resistant strains of bacteria and the recent appearance of strains with reduced susceptibility to antibiotics raised the specter of "untreatable" bacterial infections and adds urgency to the search for new infectionfighting strategies. Besides broad-spectrum activity against gram-positive and gram-negative bacteria, including human pathogens and food-spoilage bacteria, ABS was found to be more stable than nisin in different heat and enzyme treatments by Akkoç et al. $[5,48]$. Furthermore, as indicated by Akkoç et al., the antibacterial activity of ABS can proceed in extreme environmental conditions such as the potential use of the preparation for the therapy of infectious diseases and preservation of different types of foods from foodborne pathogens or food-spoilage bacteria $[5,48]$. Our present results support the idea that the antiinfective properties of $A B S$ should be tested in in vivo experiments $[4,5,6,7,8]$.

The mechanism of action regarding the antiinfective actions of $A B S$ is currently unknown. Several proteins (Homo sapiens malic enzyme 1, dynactin 5, cofilin, utrophin, mucin16 (CD164sialomucin-like-2 protein), chalcone flavanone isomerase 1 , chalcone flavanone isomerase 2, helezonal bundle transporter protein-141, hypothetical protein LOC283638 isoform 1, hypothetical protein LOC283638 isoform 2, complex 1 intermedia related protein 30 ) in ABS functional proteomic analyses represent an important step to elucidate how ABS biologically affects the components of numerous pathogens [41]. Comparative molecular studies covering proteomics, genomics, transcriptomics, and metabolomics of ABS are essentially important to shed light on this extremely vital area.

\section{Conclusion}

The pleiotropic effects of ABS on the vascular endothelium, blood cells, angiogenesis, cellular proliferation, vascular dynamics, and cellular mediators should be investigated to determine its potential role in many pathological states, including infectious diseases, wound healing, and inflammation. ABS, as a unique hemostatic agent within many crossroads of hemostasis, infection, and neoplasia, casts future experimental and clinical research to be placed into clinical management.

\section{Ethics}

Ethics Committee Approval: Is not needed for microbiological studies; Informed Consent: Not needed in this study.

\section{Authorship Contributions}

Microbiological Analyses: Ahmet Koluman; Concept: Ahmet Koluman, Nejat Akar, İbrahim C. Haznedaroğlu; Design: Ahmet Koluman, Nejat Akar, İbrahim C. Haznedaroğlu; Data Collection or Processing: Ahmet Koluman, Nejat Akar, İbrahim C. Haznedaroğlu; Analysis or Interpretation: Ahmet Koluman, Nejat Akar, İbrahim C. Haznedaroğlu; Literature Search: Ahmet Koluman, Nejat Akar, İbrahim C. Haznedaroğlu; Writing: Ahmet Koluman, Nejat Akar, İbrahim C. Haznedaroğlu.

Conflict of Interest: The authors of this paper have no conflicts of interest, including specific financial interests, relationships, and/or affiliations relevant to the subject matter or materials included.

\section{References}

1. Haznedaroglu BZ, Beyazit Y, Walker SL, Haznedaroglu IC. Pleiotropic cellular, hemostatic, and biological actions of Ankaferd hemostat. Crit Rev Oncol Hematol 2012;83:21-34.

2. Beyazit $Y$, Kurt M, Kekilli M, Goker $H$, Haznedaroglu IC. Evaluation of hemostatic effects of Ankaferd as an alternative medicine. Altern Med Rev 2010;15:329-336.

3. Ozel-Demiralp D, İ̆ci N, Ayhan B, Eğin Y, Haznedaroglu IC, Akar N. Prohemostatic and antithrombin activities of Ankaferd hemostat are linked to fibrinogen gamma chain and prothrombin by functional proteomic analyses. Clin Appl Thromb Hemost 2012;18:604-610.

4. Deveci A, Çoban AY, Tanrıverdi Çaycı Y, Acicbe Ö, Taşdelen Fışgın N, Akgüneş A, Ozatlı D, Uzun M, Durupınar B. In vitro effect of Ankaferd Blood Stopper ${ }^{\circledR}$, a plant extract against Mycobacterium tuberculosis isolates. Mikrobiyol Bul 2013;47:71-78.

5. Akkoç N, Akçelik M, Haznedaroğlu iC, Göker H, Turgut M, Aksu S, Kirazlı Ş, Fırat HC. In vitro anti-bacterial activities of Ankaferd medicinal plant extract. Turkiye Klinikleri J med Sci 2009;29:410-415.

6. Ciftci S, Keskin F, Keceli Ozcan S, Erdem MA, Cankaya B, Bingol R, Kasapoglu C. In vitro antifungal activity of Ankaferd Blood Stopper against Candida albicans. Curr Ther Res Clin Exp 2011;72:120-126.

7. Tasdelen Fisgin N, Tanriverdi Cayci Y, Coban AY, Ozatli D, Tanyel E, Durupinar B, Tulek N. Antimicrobial activity of plant extract Ankaferd Blood Stopper ${ }^{\circledR}$. Fitoterapia 2009;80:48-50.

8. Saribas Z, Sener B, Haznedaroglu IC, Hascelik G, Kirazli S, Goker H. Antimicrobial activity of Ankaferd Blood Stopper ${ }^{\circledR}$ against nosocomial bacterial pathogens. Cent Eur J Med 2010;5:198-202.

9. Beyazit Y, Kekilli M, Haznedaroglu IC, Kayacetin E, Basaranoglu M. Ankaferd hemostat in the management of gastrointestinal hemorrhages. World J Gastroenterol 2011;17:3962-3970.

10. Cohen MB, Giannella RA. Hemorrhagic colitis associated with Escherichia coli 0157:H7. Adv Intern Med 1992;37:173-195.

11. Su C, Brandt U. Escherichia coli 0157:H7 infection in humans. Ann Intern Med 1995;123:698-714.

12. Barkun AN, Moosavi S, Martel M. Topical hemostatic agents: a systematic review with particular emphasis on endoscopic application in Gl bleeding. Gastrointest Endosc 2013;77:692-700.

13. Beyazit Y, Kekilli M, Kurt M, Sayilir A, Haznedaroglu IC. Ankaferd hemostat for the management of tumoral $\mathrm{Gl}$ bleeding. Gastrointest Endosc $2011 ; 73: 1072-1073$.

14. Boškoski I, Familiari P, Costamagna G. New and emerging endoscopic therapies for gastrointestinal bleeding. Curr Opin Gastroenterol 2014;30:439-443. 
15. Jacques J, Legros R, Chaussade $S$, Sautereau D. Endoscopic haemostasis: an overview of procedures and clinical scenarios. Digest Liver Dis 2014;46:766-776.

16. Karaman A, Baskol M, Gursoy S, Torun E, Yurci A, Çelikbilek M, Guven K, Ozbakir O, Yucesoy M. Endoscopic topical application of Ankaferd Blood Stopper ${ }^{\circledR}$ in gastrointestinal bleeding. J Altern Complem Med 2012;18:6568.

17. Kurt M, Akdogan M, Onal IK, Kekilli M, Arhan M, Shorbagi A, Aksu S, Kurt OK, Haznedaroglu IC. Endoscopic topical application of Ankaferd Blood Stopper for neoplastic gastrointestinal bleeding: a retrospective analysis. Digest Liver Dis 2010;42:196-199.

18. Kurt M, Disibeyaz S, Akdogan M, Sasmaz N, Aksu S, Haznedaroglu IC. Endoscopic application of Ankaferd blood stopper as a novel experimental treatment modality for upper gastrointestinal bleeding: a case report. Am J Gastroenterol 2008;103:2156-2158.

19. Kurt $M$, Onal I, Akdogan $M$, Kekilli $M$, Arhan $M$, Sayilir A, Oztas $E$, Haznedaroglu I. Ankaferd Blood Stopper for controlling gastrointestinal bleeding due to distinct benign lesions refractory to conventional antihemorrhagic measures. Can J Gastroenterol 2010;24:380-384.

20. Ozaslan E, Purnak T, Haznedaroglu IC. Ankaferd Blood Stopper in GI bleeding: alternative for everything? Gastrointest Endosc 2011;73:185-186.

21. Ozaslan E, Purnak T, Yildiz A, Haznedaroglu IC. A new candidate as a hemostatic agent for difficult situations during variceal bleeding: Ankaferd Blood Stopper. Saudi J Gastroenterol 2011;17:145-148.

22. ASGE Technology Committee, Wong Kee Song LM, Banerjee $S$, Barth BA, Bhat Y, Desilets D, Gottlieb KT, Maple JT, Pfau PR, Pleskow DK, Siddiqui UD, Tokar JL, Wang A, Rodriguez SA. Emerging technologies for endoscopic hemostasis. Gastrointest Endosc 2012;75:933-937.

23. Yarali N, Oruc M, Bay A, Dalgıc B, Bozkaya IO, Arıkoglu T, Kara A, Tunc B. Correction to: A new haemostatic agent-Ankaferd Blood Stopper: management of gastrointestinal bleeding in an infant and other experiences in children. Pediatr Hemal Oncol 2014;31:107.

24. Wan CS, Zhou Y, Yu Y, Peng $\sqcup$, Zhao W, Zheng XL. B-cell epitope KT-12 of enterohemorrhagic Escherichia coli 0157:H7: a novel peptide vaccine candidate. Microbiol Immunol 2011;55:247-253.

25. Griffin PM, Ostroff SM, Tauxe RV, Greene KD, Wells JG, Lewis JH, Blake PA. IIInesses associated with Escherichia coli 0157:H7 infections. A broad clinical spectrum. Ann Intern Med 1988;109:705-712.

26. Aslan E, Akyüz Ü, Pata C. The use of Ankaferd in diverticular bleeding: two case reports. Turk J Gastroenterol 2013;24:441-443.

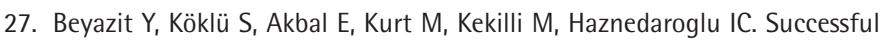
treatment of endoscopic sphincterotomy-induced early hemorrhage with application of Ankaferd Blood Stopper. Gastrointest Endosc 2010;72:13251326.

28. Beyazit Y, Kurt M, Sayilir A, Suvak B, Ozderin YO. Successful application of Ankaferd Blood Stopper in a patient with lower gastrointestinal bleeding. Saudi J Gastroenterol 2011;17:424-425.

29. Beyazit Y, Onder FO, Torun S, Tas A, Purnak T, Tenlik I, Turhan N. Topical application of Ankaferd hemostat in a patient with gastroduodenal amyloidosis complicated with gastrointestinal bleeding. Blood Coagul Fibrinolysis 2013;24:762-765.

30. Kurt M, Akdogan M, Ibis M, Haznedaroglu IC. Ankaferd Blood Stopper for gastrointestinal bleeding. J Invest Surg 2010;23:239.

31. Kurt M, Oztas E, Kuran S, Onal IK, Kekilli M, Haznedaroglu IC. Tandem oral, rectal, and nasal administrations of Ankaferd Blood Stopper to control profuse bleeding leading to hemodynamic instability. Am J Emerg Med 2009;27:631.
32. Ozaslan E, Purnak T, Yildiz A, Haznedaroglu IC. A new practical alternative for tumoural gastrointestinal bleeding: Ankaferd blood stopper. Digest Liver Dis 2010;42:594-595.

33. Ozaslan E, Purnak T, Yildiz A, Haznedaroglu IC. The effect of a new hemostatic agent for difficult cases of non-variceal gastrointestinal bleeding: Ankaferd Blood Stopper. Hepatogastroenterology 2010;57:191-194.

34. Ozseker B, Shorbagi A, Efe C, Haznedaroglu IC, Bayraktar Y. Controlling of upper gastrointestinal bleeding associated with severe immune thrombocytopenia via topical adjunctive application of Ankaferd blood stopper. Blood Coagul Fibrinolysis 2012;23:464.

35. Purnak T, Ozaslan E, Beyazit $Y$, Haznedaroglu IC. Upper gastrointestinal bleeding in a patient with defective hemostasis successfully treated with Ankaferd Blood Stopper. Phytother Res 2011;25:312-313.

36. Shorbagi A, Sivri B. Successful management of a difficult case of radiation proctopathy with Ankaferd Blood Stopper: a novel indication (with video). Gastrointest Endosc 2010;72:666-667.

37. Ozaslan E, Purnak T, Özyigit G, Akyol F, Yildiz A, Haznedaroglu IC. No prolonged effect of Ankaferd Blood Stopper on chronic radiation proctitis. Endoscopy 2010;42:E271-E272.

38. Ozaslan E, Purnak T, Yildiz A, Akar T, Avcioglu U, Haznedaroglu IC. The effect of Ankaferd blood stopper on severe radiation colitis. Endoscopy 2009;41:E321-E322.

39. Aktaş A, Er N, Korkusuz P, Zeybek D, Onur MA, Tan G, Özdemir O, Karaismailoğlu $E$, Karabulut $E$. Ankaferd-induced early soft tissue wound healing in an experimental rat model. Turkiye Klinikleri J Med Sci 2013;33:1344-1353.

40. Huri E, Beyazit Y, Mammadov R, Toksoz S, Tekinay AB, Guler MO, Ustun H, Kekilli M, Dadali M, Celik T, Astarci M, Haznedaroglu IC. Generation of chimeric "ABS Nanohemostat" complex and comparing its histomorphological in vivo effects to the traditional Ankaferd hemostat in controlled experimental partial nephrectomy model. Int J Biomater 2013;2013:949460.

41. Özel Demiralp D, Haznedaroğlu iC, Akar N. Functional proteomic analysis of Ankaferd ${ }^{\circledR}$ Blood Stopper. Turk J Hematol 2010;27:70-77.

42. Akalin C, Kuru S, Barlas AM, Kismet K, Kaptanoglu B, Demir A, Astarci HM, Ustun $\mathrm{H}$, Ertas E. Beneficial effects of Ankaferd Blood Stopper on dermal wound healing: an experimental study. Int Wound J 2014;11:64-68.

43. Cancan G, Teksoz S, Aytac E, Arikan AE, Erman H, Uzun H, Ozden F, Aydin O, Ozcan M. Effects of Ankaferd on anastomotic healing of colon. J Invest Surg 2014;27:1-6.

44. İşler SC, Demircan S, Cakarer S, Cebi Z, Keskin C, Soluk M, Yüzbaşioğlu E. Effects of folk medicinal plant extract Ankaferd Blood Stopper ${ }^{\circledR}$ on early bone healing. J Appl Oral Sci 2010;18:409-414.

45. Kaya H, Gokdemir MT, Sogut O, Demir T, Koçarslan S. Effects of folk medicinal plant extract Ankaferd Blood Stopper on burn wound healing. Acta Medica Mediterr 2013;29:497-502.

46. Tek M, Akkas I, Toptas O, Ozan F, Sener I, Bereket C. Effects of the topical hemostatic agent Ankaferd Blood Stopper on the incidence of alveolar osteitis after surgical removal of an impacted mandibular third molar. Niger J Clin Pract 2014;17:75-80.

47. Yüce $S$, Çandirli C, Yenidünya S, Muslu B. New hemostatic agent: the effect of Ankaferd Blood Stopper on healing wounds in experimental skin incision model. Turk J Med Sci 2014;44:288-294.

48. Akkoç N, Akçelik M, Haznedaroglu I, Goker H, Aksu S, Kirazli S, Fırat HC. In vitro anti-bacterial activities of Ankaferd blood stopper. Int J Lab Hematol 2008;30:95. 